\title{
Towards a Neerlandophone Postcolonial Studies
}

\author{
Elleke Boehmer \\ University of Oxford \\ Sarah De Mul \\ Open University of the Netherlands
}

Addressing the central question of the round table of DiGeSt, we would like to focus on the challenges that gender and diversity entail for the study of literatures in Dutch. Our contribution is based on the programmatic introduction to The Postcolonial Low Countries (Boehmer \& De Mul, 2012), in which we put under pressure the definitive concepts of postcolonial studies in its more conventional anglophone or francophone formation, as well as perceptions of the Low Countries, Belgium and the Netherlands, as lying outside or to the side of the postcolonial domain. We argue that literatures in Dutch raise important questions about the possible grounds on which postcolonial critical concepts might be not only translated but also generated afresh, to suit the paradoxically new contexts from which they spring.

\section{Reassessing Literary Criticism's Dutch Metropolitan Focus}

There are plentiful literary texts published in the Dutch speaking part of Belgium, Flanders, and the Netherlands that document as much as they shape the transnational formations through which the study of literatures in Dutch - or Netherlands and Flemish - is currently being challenged. Collectively these texts ask the discipline of Dutch literary criticism to abandon its traditional focus on Dutch language material read and interpreted as only pertaining to what is happening within the national boundaries of the Netherlands and Flanders.

For example, Chika Unigwe's bilingual oeuvre is characterised by complex linguistic transfers between Dutch and English language texts. ${ }^{1}$ Her debut novel De 
feniks (2005) certainly confused a number of reviewers in Flanders: the novel was based on an English language manuscript, and in 2004 Unigwe had been shortlisted for the Britain-based Caine Prize for African literature. Challenging conventional definitions of literature in Dutch and its concomitant notions of language, culture and 'race', Unigwe's oeuvre is situated within multiple, interconnected literary contexts that reach beyond its immediate locale of Flanders-Belgium. Unigwe's texts also circulate in an Anglophone book market, where they are shelved under black, African, Nigerian or African diasporic writing. Moses Isegawa's Abyssinian Chronicles (2001) about 1970s and 1980s Uganda was first published in the Netherlands as Abessijnse kronieken (1998), though originally written in English. And novels such as Abdelkader Benali's Bruiloft aan zee (1996), Rachida Lamrabet's Vrouwland (2007) and many others deal in the Netherlands' and Belgium's post-World War II histories of labour migration and their intertwinements with Italy, Morocco and Turkey. Going further back, traditions of travel writing in the Dutch or Netherlands language, too, have pointed to the permeable nature of cultural and national boundaries. A related perspective has been provided by the large and still growing body of fiction documenting the former Dutch-language colonial settlements and their legacies in Indonesia, the Caribbean and South Africa as well as the Congo under King Leopold II's and then Belgian state rule.

These texts explore and interrogate how metropolitan cultures of the Low Countries are not, nor have ever been self-sufficient entities, but rather form part of a complex network of interconnected Netherlands language or 'neerlandophone' spaces, regions and countries. ${ }^{2}$ They call for a reassessment of literary criticism's Dutch metropolitan focus and a research agenda which is transnational and postcolonial in scope. The recent growth of scholarly interest in colonial, postcolonial and multicultural literatures in Dutch bears witness to precisely such attempts to widen and re-think the scope of the field.

\section{How Postcolonial Are the Low Countries?}

Although a number of scholars have contributed to the slow development of what we would like to call 'neerlandophone postcolonial studies', the genealogy of the emerging field has not been without interruption. To begin with, the pertinence or appropriateness of postcolonial concepts brought from elsewhere to the Low Countries contexts has not always been widely accepted. The consequent sense of crisis which has marked postcolonial studies in the region virtually from its inception has further been reinforced by the absence of a shared frame through which scholars in Belgium and the Netherlands could situate their different though interrelated theories and strategies. 
How postcolonial then are the Low Countries? If the recurring public debates on the legacy of colonialism in Belgium and the Netherlands - (for example on the contemporary use of blackface in the Sinterklaas tradition) are anything to go by, then the answer to this question must be: to a significant degree, at least in experiential terms. Yet, at a conceptual level, the answer is rather different, especially if we are considering the postcolonial as something emanating from, and intricately involved with, the fabric of the regional and local cultures to which it is ascribed. The postcolonial, the Netherlands and Flanders academy is rather ready to conclude, arrived in the Netherlands and Flanders from without, in the main from Anglo-American academic contexts. It came as a cultural and theoretical import that could therefore conveniently be written off both as coming too early and at the same time as belated relative to elsewhere, to other spaces where it was previously applied - though this in a field that, it should be noted, has from the outset been beset by announcements of its immanent demise.

As our wording suggests, such answers to the question of Dutch postcoloniality have begun increasingly to sound like convenient excuses, especially where they permit Netherlands and Flanders critics and academics to pass over the postcolonial as insufficiently related to the contexts they inhabit and therefore as not worth dealing with, either now or in the future. There is no point bothering with the postcolonial, such conservative conclusions imply, especially if its critical purchase elsewhere is receding - yet this at a time when the social, cultural and political pertinence of such approaches in the Low Countries cannot be denied.

\section{The Postcolonial as Expression of Something 'Out of Joint' with the Contemporary}

Across the decades, when scholars working in the Netherlands and Flanders introduced cultural studies and postcolonial approaches, responses to their work repeatedly included the assertion that the postcolonial was inadequate methodologically or theoretically. This presumption was connected to the idea that the postcolonial was from elsewhere and hence 'new' to the Low Countries - that is, new in comparison to established interpretative literary traditions including biographical, literary historical, text-immanent or reception-oriented approaches. So it is suggestive that literary historical approaches to colonial and postcolonial literatures, such as in Theo D'haen's edited volumes Europa Buitengaats (2002), have been more readily accepted, though that legacy has also now been obscured by the importation of postcolonial theory from elsewhere. The persistent focus on the new has also been reinforced by postcolonial theorists themselves, eager, perhaps, to put the postcolonial on the Low Countries institutional academic map, and to open up space for a cultural or 
literary analysis which has so far not received the academic scrutiny it deserves in the criticism of literatures in Dutch.

In 1991, when the volume Canon onder vuur (The Canon Contested) was published, editors Ernst van Alphen and Maaike Meijer wrote that they sought to challenge "the dominant interpretative tradition that tends to persist indefinitely" 3 (Van Alphen \& Meijer, 1991, p. 105, our translation) by studying the political and socio-historical dimensions of canonical works in Dutch. The volume includes, for example, a study of racial, sexist and homophobic elements in Edgar Du Perron's Het land van herkomst (1935) or Louis Couperus's ornamental literary style and the aestheticisation of slavery in his work. Scrutinizing the imbrications of canonical texts with unbalanced racial, gender or class relations in society, the editors robustly defend their post-Marxist, postcolonial approach against the anticipated charge that deconstruction would only be concerned with noncommittal word play and jouissance, and hence be unserious and unscientific. Yet, approximately ten years later, when the bench mark volume Cultural Studies: Een inleiding edited by Jan Baetens en Ginette Verstraete (2002) introduced the discipline of Cultural Studies (including postcolonial approaches) to the Dutch academy, one detractor fiercely named Cultural Studies a "fake-discipline", charging its defenders and their critical practices with impulsiveness, inconsistency, and political correctness (Leibovici, 23 March 2002). The implicit contrast was with more traditional strands of literary theory, connoting with respectability and seriousness. Despite its relentless association with the new, the postcolonial, we conclude from these examples, has been repeatedly introduced in the academy in the Low Countries, though under different names, 'ideology critique' or 'cultural studies'. With every re-introduction of the postcolonial, however, the connotation of newness has been related to notions of inadequacy and unscientificity, assertions which become powerful arguments to sideline the postcolonial, certainly in current times when universities, particularly the Modern Languages departments, are under pressure to make cuts rather than expand.

This writing off, as our use of the word 'elsewhere' implies, is predicated on postcolonial concepts being taken as in some sense 'foreign', borrowed or non-native, something that does not suit us, or, alternatively, that we do not adequately do, or are not equal to. This too-ready Dutch acceptance of belatedness vis-à-vis the postcolonial, at times with an almost audible exclamation of relief, is a situation which paradoxically invites description as postcolonial, as a characteristic expression of late colonial or postcolonial unreadiness or dependency.

Yet, as would-be Dutch postcolonial critics, we might here remember that the postcolonial when viewed from any metropolitan perspective - which includes perspectives directed from Amsterdam or Brussels, Rotterdam or Antwerp - will 
always seem to be an expression of something 'out of joint' with the contemporary, whether it be deemed too late or too early. Over time, in other cultural spaces, this has proved to be a time-tested strategy with which social and cultural authorities in excolonial spaces have attempted to deflect the always potentially pertinent edge of postcolonial critique away from those whom it might most cogently serve.

The postcolonial, let us not forget, emerged out of situations of resistance to colonial inequality, its core concepts born out of anti-colonial struggle. And though our times may appear superficially post-postcolonial, unequal conditions analogous to those under empire, or stemming from them, continue to pertain in ex-colonizing countries like the Netherlands and Belgium today. All the more reason then to ignore postcolonialism's Dutch detractors and to draw postcolonial critical perspectives out of Low Countries conditions themselves, to find them immanent or emergent in people's lived lives, both in the so-called metropole and on its local margins, the outlying districts of Amsterdam, for example.

To be clear, what we are saying here is not that our primary objective should be to translate such perspectives across from other contexts, whereby Dutch postcolonial conditions become locked into an almost-but-not-quite situation such as famously described in Homi Bhabha's (1995) essay on colonial mimicry. While we concede that such situations of postcolonial transference and adaptation are in many ways unavoidable and can be fruitful, the primary objective in 'post-colonizing' the Low Countries academy, to coin a phrase, is to generate such perspectives from within.

\section{'Post-colonizing' the Low Countries Academy}

In an important essay, Isabel Hoving (2004, p. 16) distinguished at least two 'postcolonial' traditions that have operated in research schools and academic circuits in the Low Countries. The first group of scholars, its point of gravity at the University of Leiden, was rooted in the philological study of non-Western languages and literature. The second group, younger and less historically embedded, was trained in women's or gender studies and influenced by Anglo-American strands within cultural studies, including postcolonial studies. In her historical outline of the field, Hoving (2004, p. 17) observed that the two research traditions were "as opposed as the members of different football teams", but also conceded that scholars existed who were interested in combining these approaches and bridging the gap between the two. In the early 1990s, for example, Theo D'haen (1990; 1996; 2002; D'haen \& Termorshuizen, 1998; D'haen \& Liebregts, 2001), former Chair of English and American literature at Leiden University, founded the interdisciplinary research group 'Koloniale en Postkoloniale Literaturen' together with a range of historians, literary theorists, scholars of Indonesian, Caribbean, Dutch and French literature. 
Such cross-border research activities including traditional, philological, or anglophone postcolonial traditions have proved particularly fruitful for the elaboration of a postcolonial studies perspective directed from the Low Countries, though the concept of a postcolonialism that might be generated from within has taken more time to evolve.

Today the contours of the two research traditions outlined by Hoving remain discernible, but the field has also developed and diversified to a considerable degree. ${ }^{4}$ These developments have taken place against the background of turbulent times for the Low Countries in which issues of national citizenship, identity, religion, and immigration have become increasingly controversial. ${ }^{5}$ Hugo Brems' important literary history of literatures in Dutch Altijd weer vogels die nesten beginnen (2006, p. 177-185) discusses the diverse and historically evolving colonial and postcolonial literary traditions of the Dutch East Indies, Surinam, the Dutch Antilles and the Congo within one 'exotic' chapter of a literary history largely focused on developments and histories of the metropolitan Low Countries. But signs are also emerging that colonial and postcolonial literary studies in the region are slowly on their way to becoming integrated in the curricula of Dutch literature programmes. In the course of 2000s, three new chairs, in South African literature, Caribbean literature and Migrant Literature, were added to the already existing Chairs in Colonial and Postcolonial literature (with focus on the Dutch East Indies) to the Dutch Language and Culture course programmes at the University of Amsterdam. In most universities in Flanders and the Netherlands, scholars of literatures in Dutch are also increasingly collaborating with, and joining cultural studies research schools. At present, however, the institutional space for neerlandophone postcolonial studies is relatively insignificant in the region, certainly in comparison to the established position of postcolonial studies in English. In most taught course programmes in literatures in Dutch, the presence of postcolonial theoretical perspectives depends on the personal interests of individual scholars. This situation can only change once such perspectives are properly generated from within Dutch cultural spaces and seen to have relevance for Dutch language communities today.

Scholars working in Dutch departments in the world outside the Low Countries have generally speaking made greater efforts than their colleagues in Flanders and Belgium to open their courses and research activities to non-metropolitan neerlandophone cultures and literatures, perhaps because, from outside, the postcoloniality of the region is cast into critical relief. Relatedly, scholars working in non-Dutch departments in the Netherlands and Flanders, too, have dealt with the postcolonial to a relatively higher degree than their Dutch colleagues. ${ }^{6}$ This situation resonates with the Italian academy, where Ian Chambers (2004, p. 426) observes an engagement with postcolonial studies in many modern language departments except for the 
Italian, or in his terms "in an academic framework of an elsewhere and an other. [... As such, the other remains the object of the academic gaze, an inert item seemingly incapable of disturbing the unilateral mechanisms of cultural incorporation and the silent hegemony of an apparently 'neutral' knowledge." It depends, then, on the individual efforts of scholars working in these non-Dutch and non-Low Countries departments to transgress the linguistic boundaries of their primary field, as many postcolonial scholars effectively do.

\section{Towards a Neerlandophone Postcolonial Studies}

In recent years many piecemeal interventions have been made that have sought to make connections between international, often largely anglophone postcolonial debates on the one hand, and explicitly neerlandophone perspectives on the other. Together, these have given rise to what recently has been called "the postcolonial turn in Dutch literary criticism" (Hoving, 2010). Establishing an encounter between postcolonial theoretical discourses both from within and without the region, and the cultures and literatures of the Low Countries, this body of work aims to put under pressure certain of the definitive concepts of postcolonial studies in its anglophone formation, as well as perceptions of the Low Countries, Belgium and the Netherlands as lying outside or to the side of the postcolonial domain.

For example, the overarching objective of the volume The Postcolonial Low Countries (2012), an at once postcolonial and Low Countries located book, is two-fold, theoretical/methodological as well as historical. In effect, it explores the oxymoron it posits, of a postcolonial Netherlands and a postcolonial Flanders-Belgium. First, the book develops postcolonial concepts that are pertinent for a critical understanding of the relations between literature, colonialism and multicultural contexts in the Low Countries. Second, it reflects on historical and contemporary shifts and transformations in national literatures, identities and histories from a neerlandophone postcolonial perspective. In so doing, the volume situates itself within the interstices of two areas of inquiry - postcolonial studies and literary criticism of literatures in Dutch and has a significant dialogic contribution to make to both of these.

As this implies, The Postcolonial Low Countries theorises and brings together approaches that might be collected under the title 'neerlandophone Postcolonial Studies.' It aspires to engage with some of the most interesting postcolonial interventions that have been made in recent years by various scholars of modern language materials, including Charles Forsdick and David Murray, whose work has already exposed the ineffectiveness and indeed redundancy of mostly anglocentric attempts to divide postcolonialisms along language-specific lines. Attention has increasingly moved to addressing the heuristic costs of this predominant focus on anglophone, 
and to a lesser extent francophone, texts and contexts. This observation is not a criticism of a field which has always been subjected to intense self-interrogation, but does express some constructive disenchantment with the direction in which the discipline has evolved to date. Moreover, this anglocentrism has exacerbated the derivative way in which postcolonial concepts have often been taken up in the Low Countries, where these are seen as emanating always from elsewhere, not from within. Though the Netherlands has until recently enjoyed a long-established reputation as progressive and proactive country in relation to migration policies and ideas, at stake is what might be termed the Dutch 'dependency mentality' in relation to theory, including postcolonial theory.

From the outset postcolonial innovation outside its anglophone homelands has been hampered by the relatively limited comparative scope of the field - a comparative scope which, as the editors of Comparing Postcolonial Diasporas rightly point out, has always been "posited as essential, but its realization is perpetually deferred" (Keown, Murphy \& Procter, 2009, p. 3). It is indeed the case that Ashcroft, Griffiths and Tiffin (1989, p. 36), authors of one of the seminal textbooks of postcolonial studies The Empire Writes Back, envisioned that "the strength of post-colonial theory may well lie in its inherently comparative methodology and the hybridized and syncretic view of the modern world which this implies". In practice, however, this comparatism has not delivered on that early promise, perhaps because it conventionally operates in relation to europhone and hence formerly colonial languages, in relation to which properly postcolonial comparative and translational perspectives are more difficult to introduce. To date, postcolonial theories of literary and cultural production in the europhone languages have predictably tended to focus on the legacies of colonialism in order to create fissures in dominant narratives of national literatures and histories, rather than to interrogate the methodologies and cultural biases involved, as Gayatri Spivak begins to do in her Death of a Discipline in her discussion of Tayeb Salih (Spivak, 2003).

These constraints notwithstanding, postcolonial studies has travelled and taken root in many non-anglophone cultural and linguistic contexts, including in continental Europe. In particular, the self-conscious field-construction of 'francophone postcolonial studies' has significantly contributed to the creation of comparative links between postcolonial debates in different languages (Forsdick \& Murphy, 2003; Salhi, 2003; Donadey \& Murdoch, 2004). In Germany, Italy and Central and Eastern Europe, responses to postcolonial studies have emerged, while important postcolonial publications have appeared which expressly deploy comparative, transcolonial and cross-linguistic perspectives (Parati, 1999; 2005; Thompson, 2000; Ponzanesi, 2004; Andall \& Duncan, 2005; Poddar, Patke \& Jensen, 2008; Albrecht, 2011). These newer variants of postcolonial studies have led to a branching and frag- 
mentation of the field's already scattered objects and methods of inquiry, but it has also given substance to the emergence of a new trans-linguistic consciousness and the need to engage with other colonial trajectories and their contemporary legacies, though a focus on europhone spaces and languages still remains predominant.

The reception of postcolonial studies in other parts of the European world, as elsewhere, has of course been shaped by the respective theoretical traditions, cultural memories and colonial histories existing in these different locations. In the Low Countries, local issues concerning multiculturalism and colonial belatedness have raised important questions about the possible grounds on which postcolonial critical concepts might be not only translated but generated out of these paradoxically new contexts. Netherlands and Belgium were colonial powers with extensive overseas possessions and economies heavily dependent on colonial inputs and trade. From the colonial period onwards, contentious debates over migration, multiculturalism and hybridity/'allochtony' have radically affected and divided Belgian and Dutch cultures. $^{7}$ The postcolonial Low Countries and their historical contingencies invite us to re-think and reconstruct as adaptatively as possible the theoretical assumptions that arose from anglophone colonial history and literatures. For a properly analytical and historicized understanding of the mixed-race colonial elite in the history and literature of the Dutch East Indies, for example, conventional postcolonial ideas about 'the coloniser' and 'hybridity' have to be re-calibrated and elaborated (Stoler, 2002; 2011). The Belgian context, for its part, insists upon an approach to questions of imperialism and its aftermath that considers the relation of this aftermath to subnational tensions among the different, often divided language communities and the difficult development of the federal nation-state (Ceuppens, 2004; Ceuppens \& De Mul, 2009). In both the Dutch and the Belgian contexts, there also exists a historical disconnect between colonialism and a post-world war history of migration from Italy, Morocco and Turkey, which is very different from the British context where migrants have tended to come from the former empire. The postcolonial examination of such previously unconsidered specificities in the Low Countries demands a careful rearticulation of such postcolonial 'readymades' as hybridity, accommodation and creolization. In an era when many in the Netherlands and Belgium, in spite of their fiercely colonialist past, consider postcolonial thought 'outdated' - another word for the sigh of relief at escaping the need to engage an object of resistance - the latter critical enterprise could not be more timely. 


\section{References}

Albrecht, M. (2011). Postcolonialism, Islam and Contemporary Germany. Transit, 7(1) retrieved from http://escholarship.org/uc/item/04p001dj.

Andall, J. \& Duncan, D. (Eds.) (2005). Italian Colonialism: Legacy and Memory. Oxford \& Bern: Peter Lang AG \& European Academic Publishers.

Ashcroft, B., Griffiths. G. \& Tiffin, H. (Eds.) (1989). The Empire Writes Back. Theory and Practice in Post-Colonial Literatures. London and New York: Routledge.

Benali, A. (1996). Bruiloft aan zee. Amsterdam: Vassallucci.

Bhabha, H. (1995). Of Mimicry and Man: The Ambivalence of Colonial Discourse. In The Location of Culture (pp.85-92). London: Routledge.

Blommaert, J. \& Verschueren, J. (1992). Het Belgische migrantendebat: de pragmatiek van de abnormalisering. Antwerp: International Pragmatics Association.

Boehmer, E. \& De Mul, S. (Eds.) (2012). The Postcolonial Low Countries. Literature, Colonialism and Multiculturalism. Basingstoke: Lexington Books.

Brems, H. (2006). Altijd weer vogels die nesten beginnen. Geschiedenis van de Nederlandse literatuur, 1945-2005. Amsterdam: Prometheus.

Ceuppens, B. (2004). Congo Made in Flanders? Koloniale Vlaamse visies op 'blank' en 'zwart' in Belgisch Congo. Gent: Academia Press.

Ceuppens, B. (2006). Allochthons, Colonizers, and Scroungers: Exclusionary Populism in Belgium. African Studies Review, 49(2), 147-186.

Ceuppens, B. \& De Mul, S. (2009). De vergeten Congolees. Kolonialisme, post-kolonialisme en multiculturalisme. In K. Arnaut, S. Bracke, B. Ceuppens, S. De Mul, N. Fadil, \& M. Kanmaz (Eds.), Een leeuw in een kooi. De grenzen van het multiculturele Vlaanderen (pp.4867). Antwerpen-Amsterdam: Meulenhoff-Manteau.

Chambers, I. (2004). The Mediterranean. A Postcolonial Sea. Third Text, 18(5), 423-433.

D'haen, T. (1990). Herinnering, herkomst, herschrijving: Koloniale en post-koloniale literaturen. Leiden: TCZOAO.

D'haen, T.(1996). Weer-Werk: schrijven en terugschrijven in koloniale en postkoloniale literaturen. Leiden: TCZOAO.

D'haen, T. \& Termorshuizen, G. (1998). De geest van Multatuli: proteststemmen in vroegere Europese koloniën. Leiden: TCZOAO.

D'haen, T. \& Liebregts (2001). Tussen twee werelden: het gevoel van ontheemding in de postkoloniale literatuur. Leiden: TCZOAO.

D'haen, T. (2002). Europa buitengaats: koloniale en postkoloniale literaturen. Amsterdam: Bert Bakker.

Donadey, A. \& Adlai Murdoch, H. (2004). Postcolonial Theory and Literature in a Francophone Frame. University Press of Florida: Gainesville.

Forsdick, C. \& Murphy, D. (Eds.) (2003). Francophone Postcolonial Studies: A Critical Introduction. London: Routledge. 
Geschiere, P. (2009). The Perils of Belonging. Autochthony, citizenship, and exclusion in Africa and Europe. Chicago: University Press.

Hoving, I. (2010). Review. The Postcolonial Turn in Dutch Literary Criticism. Journal of Dutch Literature 1(1), 114-122 retrieved from http://journalofdutchliterature.org/cgi/t/ text/get-pdf?c $=$ jdl;idno $=0101 \mathrm{a} 06$.

Hoving, I. (2004). Niets dan het heden: Over Jamaica Kincaid, de postkoloniale literatuurstudie, en wat er van ons terecht moet komen. In M. van Kempen, P. Verkruijsse \& A. Zuiderweg (Eds.), Wandelaar onder de palmen: Opstellen over koloniale en postkoloniale literatuur en cultuur (pp.15-28). Leiden: KITLV Uitgeverij.

Isegawa, M. (1998). Abessijnse kronieken. Amsterdam: De Bezige Bij.

Isegawa, M. (2001). Abyssinian Chronicles. New York: Vintage International.

Keown, M., Murphy D. \& J. Procter (Eds.) (2009). Comparing postcolonial Diasporas. London \& New York: Palgrave Macmillan.

Lamrabet, R. (2007). Vrouwland. Antwerpen/Amsterdam: Meulenhoff-Manteau.

Leibovici, S. (23 March 2002). De zeloten van Cultural Studies. Een vibrerende nepstudie. De Groene Amsterdammer retrieved from http://www.groene.nl/artikel/een-vibrerendenepstudie.

Minnaard, L. (2013). Multiculturality in the Dutch literary field. In W. Beschnitt, S. De Mul \& L. Minnaard (Eds.), Literature, language, and multiculturalism in Scandinavia and the Low Countries. Amsterdam/New York: Rodopi.

Parati, G. (1999). Mediterranean Crossroads. Migration Literature in Italy. Madison, N.J.: Fairleigh Dickinson UP.

Parati, G. (2005). Migration Italy. The Art of Talking Back in a Destination Culture. Toronto: University of Toronto Press.

Du Perron, E. (1935). Het land van herkomst. Amsterdam: Querido.

Poddar, P. Patke, R. \& L. Jensen (2008). Historical Companion to Postcolonial Literatures Continental Europe and Its Empires. Edinburgh: Edinburgh University Press.

Ponzanesi, S. (2004). Paradoxes of Post-Colonial Culture. Contemporary Women Writers of the Indian and Afro-Italian Diaspora. Albany: State University of New York Press.

Salhi, K. (2003). Francophone Post-colonial Cultures: Critical Essays. Lanham: Lexington Books.

Spivak, G. (2003). Death of a Discipline. New York: Columbia University Press.

Stoler, A. L. (2002). Carnal Power and Imperial Knowledge. Race and the Intimate in Colonial Rule. Berkeley: University of California Press.

Stoler, A. L. (2011). Along the Archival Grain. Epistemic Anxieties and Colonial Common Sense. Princeton: Princeton University.

Thompson, E. M. (2000). Imperial Knowledge. Russian Literature and Colonialism. Westport, Connecticut: Greenwood Press.

Unigwe, C. (2007). De feniks. Amsterdam/Antwerpen: Meulenhoff/Manteau.

Unigwe, C. (2007). Fata Morgana. Amsterdam/Antwerpen: Meulenhoff/Manteau. 
Unigwe, C. (2009). On Black Sisters' Street. London: Jonathan Cape.

Van Alphen, E. \& Meijer, M. (Eds.) (1991). Canon onder vuur. Nederlandse literatuur tegendraads gelezen. Amsterdam: Van Gennep.

Verthé, A. \& Henry, B. (1961). Geschiedenis van de Vlaams-Afrikaanse letterkunde. Leuven: Davidsfonds.

\section{Notes}

1. Though the Dutch language novel Fata Morgana (2007) was published years before the English language edition On Black Sisters' Street (2009), the former was based on an English language manuscript and cannot really be called the original source text in the traditional sense of the term.

2. In this contribution, we prefer to use the umbrella term 'neerlandophone' instead of 'Dutch' to refer to the manifold Netherlands languages variations spoken by persons, groups or localities across the globe, including the Netherlands, Flanders-Belgium, Suriname, the Caribbean island nations of Aruba, Curaçao, and Sint-Maarten, parts of France and Germany, Indonesia, South Africa, the United States, Canada, and Australia.

3. "de dwingende interpretatietraditie, die de neiging heeft zich oneindig voort te zetten $[\ldots]$ ".

4. This cursory outline pertains primarily to the Netherlands. In Flanders, the situation is rather different. Generally Flemish-African literature is a relatively small corpus and to date a rather marginal object of study; existing literary histories and related critical paradigms often date back to the colonial period, for example Verthé \& Henry (1961).

5. The politically inspired assassinations of the right-wing politician Pim Fortuyn in 2002, the antiIslam film director Theo van Gogh in 2004 and death treats to the public figure of Ayaan Hirsi Ali shook the nation. In 2010 the Netherlands saw the stunning rise to political power of Geert Wilders' populist anti-Islam party PVV. These events support the assumption, increasingly reiterated nowadays, that the traditional idea of tolerance as a Dutch national virtue is nowadays replaced by the idea of tolerance as a naive form of blindness.

6. During the last years, two postcolonial research platforms were inaugurated in the Netherlands and Flanders-Belgium by scholars working primarily on postcolonial literatures in English, French, Italian and Comparative Literature. The Platform for Postcolonial Readings, organised by scholars at the Free University of Brussels, Leuven and Leiden University, is an open network for scholars of postcolonial and globalisation studies in Belgium and the Netherlands. The Postcolonial Studies Initiative, coordinated by Utrecht University is a platform intended for research into postcolonial issues in Europe.

7. Stemming from the Greek roots allos/other, authos/same and chtoon/soil, the term 'allochtoon' has nowadays replaced the term 'migrant' to refer to the generations of citizens with non-native cultural backgrounds living in Flanders and the Netherlands. According to the Dutch governmental CBS (Centraal Bureau voor de Statistiek/Central Office for Statistics), an 'allochtoon' is a person of whom at least one parent was born abroad, see Minnaard (2013). For critical analyses of the related terms 'migrant'/'allochtoon' and 'autochtoon', see Blommaert \& Verschueren (1992); Ceuppens (2006); Geschiere (2009). 